Iranian (Iranica) Journal of Energy \& Environment
Journal Homepage: www.ijee.net
IJEE an official peer review journal of Babol Noshirvani University of Technology, ISSN:2079-2115

Research Note

\title{
Watershed Hydrological Responses to Changes in Land Use and Land Cover at Hangar Watershed, Ethiopia
}

\author{
A. W. Galata*, T. A. Demissei, M. K. Leta
}

Department of Hydraulic and Water Resouces Engineering, Faculty of Civil and Environmental Engineering, Jimma University Institute of Technology, Jimma, Ethiopia

\section{$P A P E R \quad I N F O$}

\section{Paper history:}

Received 19 January 2020

Accepted in revised form 23 February 2020

\section{Keywords:}

Land Cover Change

Land Use

Soil and Water Assessment Tool Model

Watershed Hydrology

\begin{abstract}
$A \quad B \quad S \quad T \quad R \quad A \quad C \quad T$
The various water resources project planning and implementation need the knowledge of factors influencing watershed hydrology. Therefore, this study analyzed Hangar watershed hydrological responses to land use/land cover change (LULCC) from 1987 to 2017. In addition to the LULC data, the in put data used for the soil and water assessment tool (SWAT) model simulation were the DEM data, soil data, and climatic data. The model calibrated and validated using measured streamflow data of 13 years (1990-2002) and nine years (2003-2011), respectively. The result after simulation indicated that the annual total water yield of the watershed decreased. The annual simulated stream flow through the study period is increased for wet and short rainy season whereas, decreased for dry season. An increase of wet season flow may result in flooding, and the reduction of dry season flow may affect water scheme practice. Therefore, this study enables the concerned body to curve the changes in LULC towards increasing vegetation cover so that, surface runoff that contributes to wet season flow will be reduced and infiltration that supply groundwater from which dry season/base flow contributed will be increased.
\end{abstract}

\section{INTRODUCTION}

Land use/land cover change affects the different hydrological components like; interception, infiltration, and evapotranspiration, thereby influencing soil moisture content, runoff generation (both process and volume), and streamflow regimes [1,2]. Climate models have even shown that the land use and land cover change affect global precipitation and temperature patterns [3], which influences the hydrological process. The spatial and temporal variability of watershed resources (particularly land cover change and climatic change) have a significant influence on the quantity and quality of river water flow [4]. Many studies performed in different parts of the country, for instance, [5] in Headstream of Abbay Watershed; [6] in northern Ethiopian highlands addressed a common concern as the water resource degradation brought about by the decrease in the area under natural vegetation and its conversion into other types of land use that are human-managed systems. Human-induced landuse changes such as deforestation, afforestation, and agricultural and urban development within the river basin can affect the hydrological cycle [7]. Human health and welfare, food security, and industrial developments are dependent on adequate supplies of suitable water; however, water resources affected by many parameters [8]. Both conversion and modifications of land use and land cover have critical environmental consequences through their impacts on soil, water, biodiversity, and microclimate, and hence, contribute to watershed degradation [4]. Both climate and land use and land cover change have a great influence on the hydrological response of a watershed [1]. Land-use changes in a watershed can influence water supply by altering hydrological processes such as infiltration, groundwater recharge, base flow, and runoff [9]. Its influence is direct on climate and water resources on the ground. Land under little vegetation cover [10], is subjected to high surface runoff, low water retention, and low infiltration rate. The performed studies about the factors that could affect the hydrological process at the watershed level are not much as in the largest basins of the country. Studies of LULC dynamics at the subwatershed level are rare in Ethiopia [11]. To predict the demands for different water resources schemes, enough studies should carry out about the factors affecting the watershed. However, no study carried out about factors that affect the hydrology of the 
watershed behavior and their relation to land use/land cover changes of Hangar Watershed, which can be a relevant consideration in the design of integrated watershed management and of appropriate sustainable land management practices, strategies, and policies. Since the study watershed located in an agricultural area, the change in land use and land cover continued unless the factors facilitating these changes identified and measures need to take recommended. However, at the study area, no software-based land use and land cover changes determination carried out. To fill this gap, the hydrological responses of the Hangar watershed to the changes in land use/land cover evaluated by using the SWAT model.

\section{MATERIAL AND METHOD}

\section{Description of the study area}

Hangar River watershed located in west-central Ethiopia. The river emerges from the Horo Guduru Wollega zone near Jardaga Jarte district, and it flows south-west to join Didessa River, which is a tributary of the Blue Nile (also called the Abbay River basin in Ethiopia). Hangar enters the Didessa approximately halfway between the town of Nekemt and the village of Cherari at a latitude and longitude of $9^{\circ} 35^{\prime} \mathrm{N}$ and $36^{\circ} 2^{\prime} \mathrm{E}$, respectively. It has several tributaries that cover an area of nearly $7673.87 \mathrm{~km}^{2}$. The topography or elevation of the watershed ranges from 844 to $3207 \mathrm{~m}$ above mean sea level. Generally, the Hangar River watershed geographically located between $36^{\circ} 31^{\prime} 41^{\prime \prime}$ to $37^{\circ} 06^{\prime}$ 50" East longitude and $9^{\circ} 41^{\prime} 58^{\prime \prime}$ to $9^{\circ} 59^{\prime} 56^{\prime \prime}$ North Latitude (Figure 1). The regional geology of the study area developed from three types of geological terrains. These are Quaternary sediments, Paleozoic to Mesozoic rock, Precambrian rock (from youngest to oldest). Most of the study area is covered with intrusive Precambrian rocks mainly granite with coarsegrained texture and massive, which is overlaid by thick black to brownish cotton soil. Climatic elements like rainfall, temperature, relative humidity, sunshine, and wind can affect by geographic location and altitude. As per the data collected from the National Metrological Service Agency (NMSA), the study area receives heavy rainfall from June to September and experiences a limited amount of rainfall for the left seven months. In the study area, the average maximum temperature experienced in the February, March, and April, whereas the average minimum temperature occurred in the September, October, and November.

\section{Data collections and sources}

The dataset collected from primary and secondary sources. Primary data are the ground truth data about the LULC and gained from the study area by using different methods such as; interviewing with those who are living at the site, discussing with others who have information about the field and collected with GPS for the recent period during field observation. Whereas, secondary data are recorded data, collected from different sources. All-weather data collected from the National Meteorological Service Agency (NMSA) of Ethiopia. Land use and land cover data of 1987 (Landsat-5 TM), 2001 (Landsat-7 ETM+), and 2017 (Landsat-8 OLI_TIRS) acquired from U.S Geographic Survey. Soil and

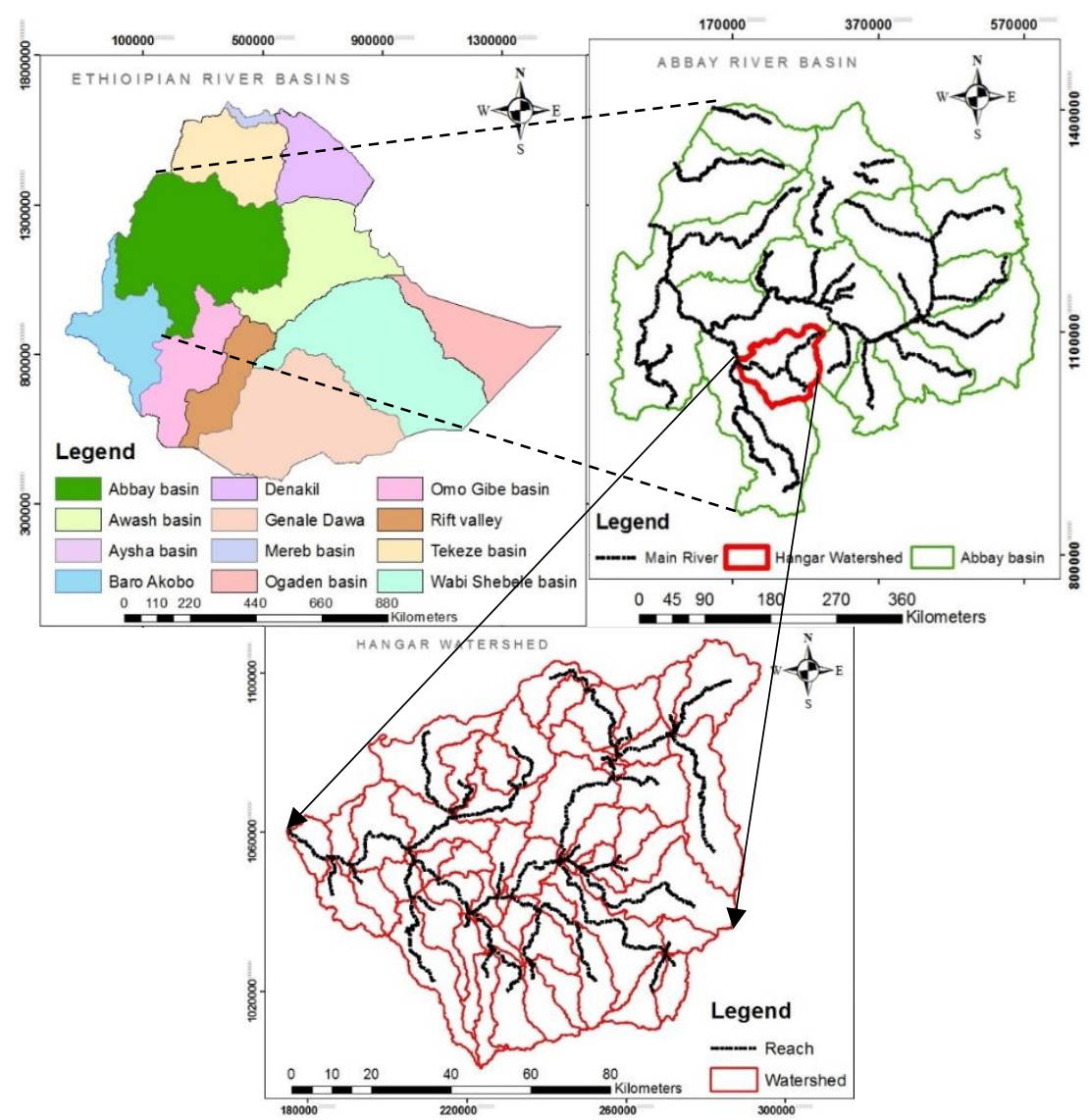

Figure 1. Location of the study area 
streamflow data collected from GIS and hydrology department of Ministry of Water, Irrigation, and Electricity (MoWIE) of Ethiopia. There are eight soil types in the study watershed. They are Haplic Alisols (38.14\%), Eutric Leptosols (2.37\%), Haplic Nitisols (3.6\%), Eutric Vertisols $(0.1 \%)$, Dystric Leptosols (12.94\%), Haplic Acrisols (26.84\%), Rhodic Nitisols (16.0\%) and Haplic Arenosols $(0.01 \%)$. Topographic data, DEM acquired from the website of Alaska satellite facility.

\section{Data analysis}

Since the study area could not be covered with one image, more images of Digital Elevation Model (DEM) of 12.5 by $12.5 \mathrm{~m}$ resolution downloaded and mosaicked with the aid of Arc GIS 10.6 before extracting the area of interest. The SWAT model needs full daily weather data to analysis and generates the result. The collected missed daily rainfall and temperature data from the National Metrological Service Agency filled by Xlsat 2018 program, where multiple leaner regression used to fill missed daily rainfall data from neighboring stations and missed maximum and minimum daily temperature data filled by average multiple imputation methods. Inconsistency of climatic data could happen during record because of changes in conditions, changes in instrumentation, changes in gauge location, and changes in observation practices. Before using any weather data, it is necessary to analyze and checks whether it is consistent or not. For this particular study, the consistency of recorded data for four stations checked by double mass curve and no need for corrections because they correlated. The three stations (Alibo, Hangar Gute, and Gelila) contain only precipitation and temperature (minimum and maximum) data. However, Nekemte station contains all climatic data such as precipitation, temperature (minimum and maximum), sunshine, relative humidity, and wind speed. Therefore, sunshine, relative humidity, and wind speed data generated for Alibo, Hangar Gute and Gelila stations from Nekemte station. The parameters required for weather generator calculated using software programs PCP STAT.exe and dew02.exe. The program PCP STAT.exe using daily precipitation calculated the statistical parameters of daily precipitation data. Whereas, the program dew02.exe calculated the average daily dewpoint temperature per month using daily air temperature and humidity data. The calculated parameters for weather generator adjusted and added into the SWAT weather database table.

\section{SWAT model setup}

The SWAT model designed to predict the impact of land management practices on water, sediment, and agricultural chemical yields in large complex watersheds with varying conditions over long periods [12]. The SWAT model proceed by sequential procedures to give output for which past procedure is an input for the next one. Looking for the next task without properly completing one of these steps is impossible. After completion of SWAT database preparation, the first procedures in the SWAT model is to create a new project or DEM set up of having identified folder in which the whole work could executed. The watershed delineation interface in Arc SWAT separated into five sections, including DEM Set Up, DEM-based Stream Definition (flow direction and accumulation and drainage network generation), Outlet, and Inlet Definition, Watershed Outlet(s) Selection and Definition and Calculation of Sub-basin parameters. In this study, the smaller area (7600 ha) provided to get 61 subbasins of the Hangar river basin, and outlet is defined, in which it later taken as a point of calibration of the simulated flows. The multiple scenarios that account for $15 \%$ land use, $15 \%$ soil, and $15 \%$ slope threshold combination give a better estimation of streamflow [13]. As the percentage of land use, slope, and soil threshold increases, the actual evapotranspiration decreases due to eliminated land-use classes [14]. Taking the objective of the study into consideration and paying attention to characteristics of HRUs as the key factors affecting the streamflow, land use, soil and slope class threshold of $10 \%, 15 \%$, and $15 \%$ used respectively. Hence, the Hangar River basin results in 196 HRUs in the whole basin. The prepared soil layers, classified LULC and slope layers, and delineated Watershed by Arc SWAT overlapped $100 \%$. The input to the model finalized, and the output generated and read after running the model in the SWAT simulation. For this study, the SWAT model was run with the meteorological data of 1987 to 2017 by keeping three years (1987-1989) for the warm-up period to avoid the impacts of the initial conditions of the model.

\section{RESULTS AND DISCUSSION}

Calibration of the model

The SWAT model generated output using model input parameters, which kept within a realistic uncertainty range [12]. Therefore, to have the real knowledge of the watershed, calibration carried out using SWAT-CUP (SWATCalibration and Uncertainty Programs) through Sequential Uncertainty Fitting-2 (SUFI-2). The SWAT model output calibrated using 13 years of measured streamflow data (19902002). The obtained $R^{2}$, NSE, and PBIAS values during calibration were $0.87,0.82$, and +1.4 , respectively. The graphical comparison of observed and simulated flow during calibration shown in Figures 2 and 3.

\section{Validation of the model}

For the catchment with longtime series, split sample test is involved [15] for which one part used to calibrate the model, and the second part is used for testing (validating) if calibrated parameters produced simulations which satisfy goodness-of-fit tests. Therefore, since it has thirty-one years of data, a split-sample test was applied in this watershed for which measured streamflow data of 22 years was scaled $60 \%$ (1990-2002) for calibration to 40\% (2003-2011) for validation. The value of $\mathrm{R}^{2}$, NSE, and PBIAS obtained during validation were $0.89,0.88$, and +1.2 , respectively. $R^{2}$ is used to evaluate the accuracy of the simulated value when compared with the observed values, whereas the goodnessof-fit measured with NSE [15]. In general, the performance indices gained during the calibration and validation periods indicated an acceptable performance rate of the model in simulating the hydrological impacts of LULC changes over the 1987 to 2017 periods. The graphical comparison of observed and simulated flow during validation shown in Figures 4, and 5. 


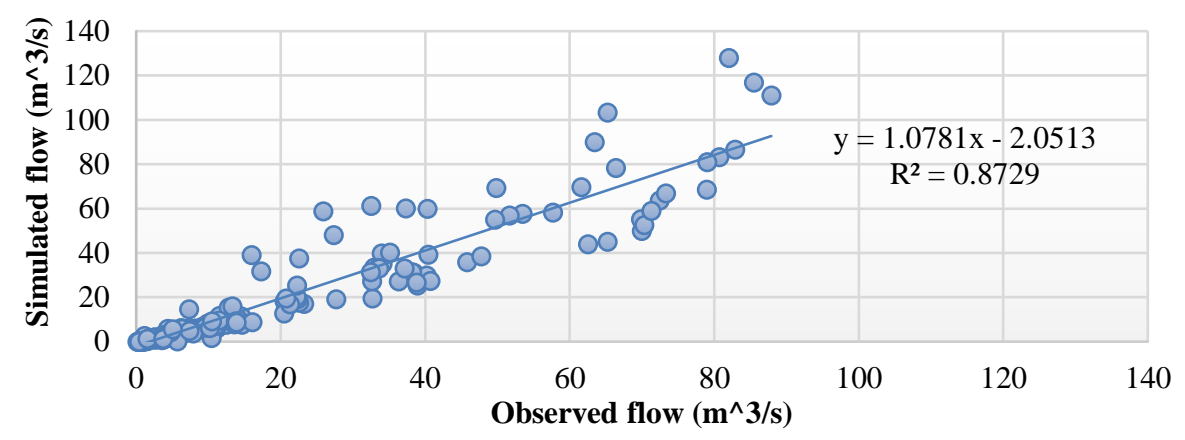

Figure 2. Graph of simulated versus observed flow during calibration

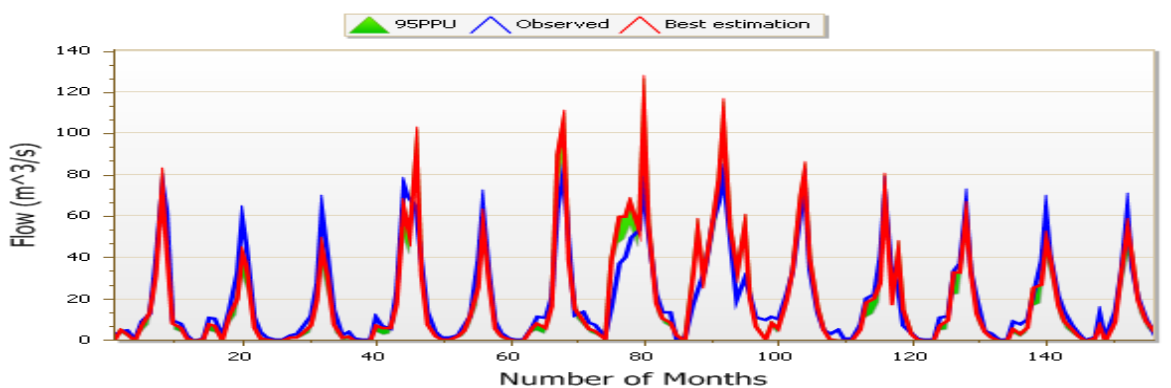

Figure 3. Hydrograph of monthly simulated and observed flow during calibration

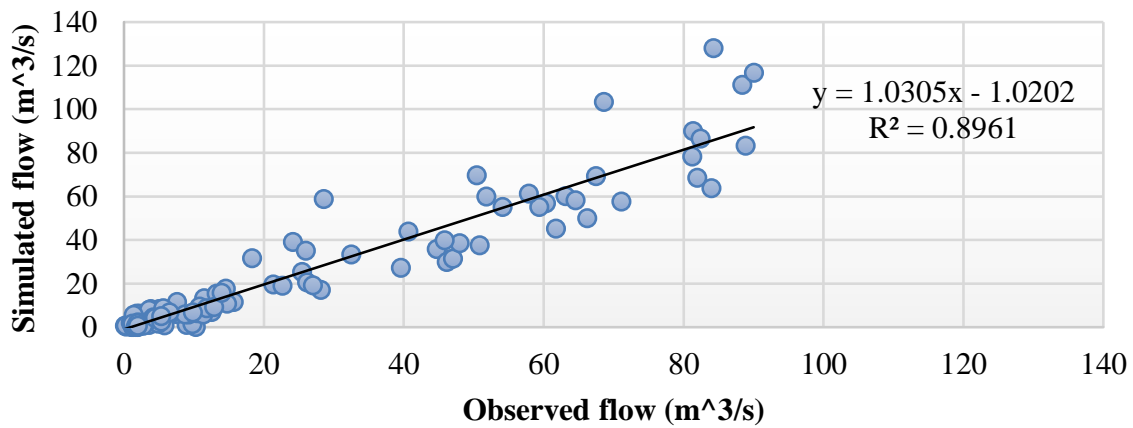

Figure 4. Graph of simulated versus observed flow during validation

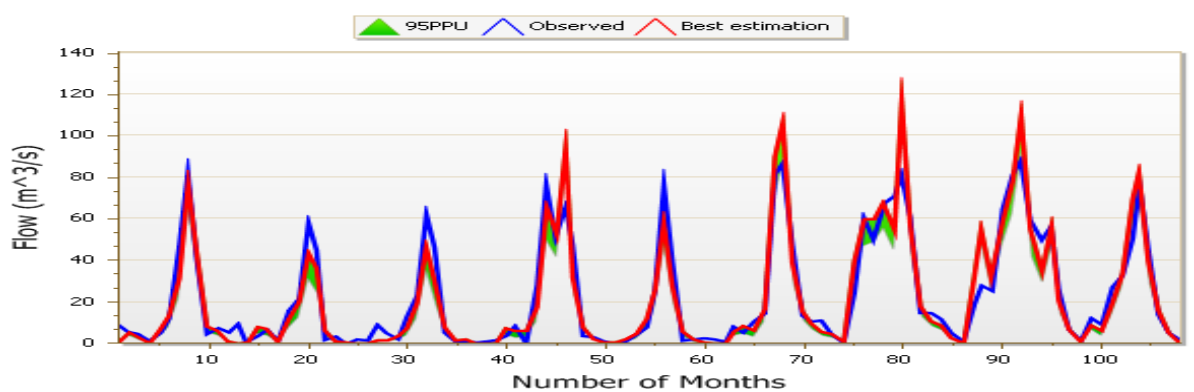

Figure 5. Hydrograph of monthly simulated and observed flow during validation

Watershed hydrological responses to changes in LULC

The study indicated that (Table 1), the average annual surface runoff of the watershed increased from $306.55 \mathrm{~mm}$ in 1987 LULC to $316.74 \mathrm{~mm}$ in 2001 and $327.42 \mathrm{~mm}$ in 2017 LULC. The total sediment load also increased from $209.76 \mathrm{~mm}$ to $220.75 \mathrm{~mm}$ to $221.32 \mathrm{~mm}$ for LULC of 1987,2001 , and 2017, respectively. Whereas, the total aquifer recharge decreased from $336.9 \mathrm{~mm}$ in 1987 LULC to $325.34 \mathrm{~mm}$ in 2001 and $312.95 \mathrm{~mm}$ in 2017 LULC. The reduction of percolation out of soil was consistent with that of deep aquifer recharge. The annual average total water yield of the watershed decreased from $790.26 \mathrm{~mm}$ to $777.38 \mathrm{~mm}$ to $766.08 \mathrm{~mm}$ for LULC of 1987, 2001, and 2017, respectively. These changes were due to the decreased in land cover and increased cultivated land and built-up area. Covered land with natural vegetation undergone reduced surface runoff, and infiltration becomes high. For the case of urbanization, land could be paved to take water in and surface runoff increased. The soil in a cultivated 
area could be easily detached, and transported to downstream than covered land with vegetation, which would be resulted in increased sediment load. For this study, increased surface runoff has resulted in sediment load increment. Reduction of total aquifer recharge is resulted from increased surface runoff, which reduces infiltration capacity of the soil; thereby percolation of water from the soil to recharge deep aquifer decreased. The expansion of agricultural land and built-up area over other land covers results in the increase of surface runoff following rainfall events and causes alteration in soil moisture conditions and groundwater storage. The water infiltrated into the ground to recharge the shallow aquifer reduced. Therefore, the change in the components of streamflow due to LULCC expected to decrease dry season discharge, which mostly comes from base flow (shallow aquifer contribution) and increases discharge during the wet months, which supplied from surface runoff. The finding of the study is compatible with other studies carried out in different parts of the country for instance, by Mengistu [16] in Hare Watershed, Ethiopia (the contribution of surface runoff has increased from $39 \%$ to $44 \%$ due to the LULCC occurred between the period 1975 to 2004). Similarly, the study by Gashaw et al. [17] in the Andassa Watershed, Blue Nile Basin, Ethiopia indicated as surface runoff increased from $222.1 \mathrm{~mm}$ to $233.7 \mathrm{~mm}$ to $242.8 \mathrm{~mm}$ in the LULC of 1985, 2000 and 2015, respectively while groundwater reduced from $126.5 \mathrm{~mm}$ to $121.9 \mathrm{~mm}$ and116.7 $\mathrm{mm}$ in the corresponding year, respectively. The annual stream flow through the study period is increased for wet season (June to September), and the short rainy season (March to May) whereas, decreased for dry season (October to February) (Table 2) (Figure 6). The increased cultivated land and builtup area and extraction of vegetation covers also expected to become the reason for these changes. Since land cover such as forest, grassland, and rangeland decreased, surface runoff increased that contributed to the increment of wet and short rainy season streamflow. The infiltration rate of the watershed reduced due to the expansion of the built-up area. The reduction in infiltration rate decreased shallow aquifer from which dry season streamflow contributed. The low contributed shallow aquifer resulted in dry season streamflow reduction. The comparison of simulated streamflow for the LULC of the three periods summarized in Table.2. The finding of the study is consistent with other studies. For example, the result of a study by Mengistu [16] in Hare watershed indicated that the mean monthly discharge for wet months had increased by $12.5 \%$ while in the dry season decreased by $30.5 \%$ during the $1992-2004$ periods due to the LUCC. The study by Getachew and Melesse [18] in the Angereb Watershed, Ethiopia has also shown that the mean wet monthly flow for LULC of 2011 increased by $39 \%$ compared to the 1985 LULC while the dry average monthly flow decreased by $46 \%$ in 2011 compared to LULC of 1985.

TABLE 1. The impacts of LULCC of 1987-2001, 2001-2017, and 1987-2017 periods on water balance components

\begin{tabular}{|c|c|c|c|c|c|c|}
\hline \multirow{2}{*}{ Water balance components } & \multirow{2}{*}{1987} & \multirow{2}{*}{2001} & \multirow{2}{*}{2017} & \multicolumn{3}{|c|}{ Rate of changes (\%) } \\
\hline & & & & 1987-2001 & 2001-2017 & 1987-2017 \\
\hline SURQ, mm & 306.55 & 316.74 & 327.42 & 10.19 & 10.68 & 20.87 \\
\hline LATQ, mm & 66.96 & 61.28 & 57.79 & -8.48 & -5.70 & -13.69 \\
\hline PERC, mm & 336.9 & 325.35 & 312.95 & -11.55 & -12.40 & -23.95 \\
\hline AQ recharge, $\mathrm{mm}$ & 336.9 & 325.34 & 312.95 & -11.56 & -12.39 & -23.95 \\
\hline $\mathrm{ET}, \mathrm{mm}$ & 320.5 & 314.4 & 310 & -1.90 & -1.40 & -3.28 \\
\hline TSL, t/ha & 209.76 & 220.75 & 231.32 & 4.98 & 4.57 & 9.32 \\
\hline TWYLD, mm & 790.26 & 777.38 & 766.08 & -12.88 & -11.3 & -24.18 \\
\hline
\end{tabular}

SURQ-Surface runoff, LATQ-Lateral soil flow, PERC-percolation, AQ-aquifer recharge, ET-Evapotranspiration, TSL -total sediment loading, and TWYLD-total water yield

TABLE 2. The impacts of LULCC of 1987-2001, 2001-2017, and 1987-2017 periods on streamflow

\begin{tabular}{|c|c|c|c|c|c|c|}
\hline \multirow{2}{*}{ Season } & \multicolumn{3}{|c|}{ Annual simulated streamflow $\left(\mathrm{m}^{3} / \mathrm{s}\right)$} & \multicolumn{3}{|c|}{ Rate of changes (\%) } \\
\hline & 1987 & 2001 & 2017 & 1987-2001 & 2001-2017 & 1987-2017 \\
\hline Wet & 3930.80 & 4061.30 & 4231.20 & 3 & 4 & 7 \\
\hline Short rainy & 830.90 & 848.70 & 892.70 & 2 & 5 & 7 \\
\hline Dry & 1148.90 & 1130.90 & 1120.20 & -2 & -1 & -2 \\
\hline
\end{tabular}

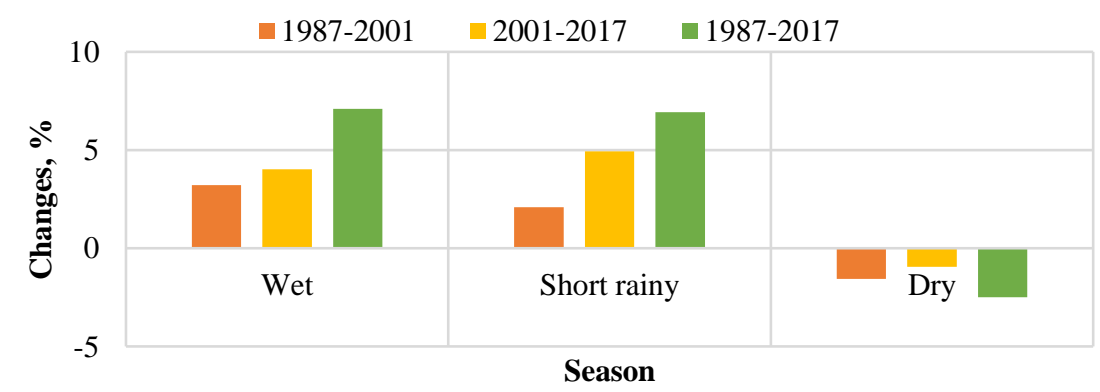

Figure 6. Comparison of simulated streamflow for LULCC of 1987-2001, 2001-2017 and 1987-2017 periods 


\section{CONCLUSIONS}

The land use and land cover changes have significant impacts on the functioning of socioeconomic and environmental systems. In Ethiopia, most parts of the regions are vulnerable to problems concerning food production that mostly affects rural livelihood, mainly due to an increase in population on the one hand and inappropriate management of resources on the other hand. The SWAT model used the result of LULCCs to evaluate the hydrological responses of the watershed to changes in LULC. The SWAT-CUP used for sensitivity analysis of parameters, calibration, and validation. It found that CN2, SURLAG, and CANMX are the most three top sensitive parameters in the study area. For both calibration and validation, the SWAT model performed correctly, having the value of NSE, PBIAS, and coefficient of determination $\left(\mathrm{R}^{2}\right)$ in a very good range.

Generally, the study revealed that the expansions of cultivated land and built-up area and the extraction of the forest, grassland, and rangeland during the 1987 to 2017 periods had decreased the average annual total water yield contribution of the watershed, lateral flow, percolation from the soil, evapotranspiration, aquifer recharge, and dry season streamflow. Conversely, the LULC changes had increased surface runoff, total sediment yield, wet and short rainy season streamflow.

\section{ACKNOWLEDGMENT}

I sincerely thank my principal advisor Dr. Ing Tamene Adugna and my co-advisor, Mr. Megersa Kebede, for their advice during the study and constructive comments on the manuscript.

\section{REFERENCES}

1. Dwarakish, G.S. and Ganasri, B.P., 2015. Impact of land use change on hydrological systems: A review of current modeling approaches. Cogent Geoscience, 1(1), pp.1-18.

2. Tekleab, S., Mohamed, Y., Uhlenbrook, S. and Wenninger, J., 2014. Hydrologic responses to land cover change: the case of Jedeb mesoscale catchment, Abay/Upper Blue Nile basin, Ethiopia. Hydrological Processes, 28(20), pp.5149-5161.

3. Chase, T.N., Pielke Sr, R.A., Kittel, T.G.F., Nemani, R.R. and Running, S.W., 2000. Simulated impacts of historical land cover changes on global climate in northern winter. Climate Dynamics, 16(2-3), pp.93105 .

4. "Tufa, D.F., Abbulu, Y.E.R.R.A.M.S.E.T.T.Y. and Srinivasarao, G.V.R., 2014. Watershed Hydrological Response to Changes in Land
Use/Land Covers Patterns of River Basin: A Review. International Journal of Civil, Structural, Environmental and Infrastructure Environmental and Infrastructure Engineering Research and Development, 4, pp.157-170.

5. Solomon, A., 2005. Land-Use and land-Cover Change in Headstream of Abbay Watershed. Doctoral dissertation, Addis Ababa University, Ethiopia.

6. Zeleke, G. and Hurni, H., 2001. Implications of land use and land cover dynamics for mountain resource degradation in the Northwestern Ethiopian highlands. Mountain Research and Development, 21(2), pp.184-191.

7. Babar, S. and Ramesh, H., 2015. Streamflow response to land use-land cover change over the Nethravathi River Basin, India. Journal of Hydrologic Engineering, 20(10), pp.1-11.

8. Kebede, W., Tefera, M., Habitamu, T. and Alemayehu, T., 2014 Impact of land cover change on water quality and stream flow in lake Hawassa watershed of Ethiopia. Agricultural Sciences, 2014(5), pp.647-659.

9. Lin, Y.P., Hong, N.M., Wu, P.J., Wu, C.F. and Verburg, P.H., 2007. Impacts of land use change scenarios on hydrology and land use patterns in the Wu-Tu watershed in Northern Taiwan. Landscape and Urban Planning, 80(1-2), pp.111-126.

10. Bewket, W., 2002. Land cover dynamics since the 1950s in Chemoga watershed, Blue Nile basin, Ethiopia. Mountain Research and Development, 22(3), pp.263-269.

11. Miheretu, B.A. and Yimer, A.A., 2018. Land use/land cover changes and their environmental implications in the Gelana sub-watershed of Northern highlands of Ethiopia. Environmental Systems Research, 6(7), pp.1-12.

12. Arnold, J.G., Moriasi, D.N., Gassman, P.W., Abbaspour, K.C., White, M.J., Srinivasan, R., Santhi, C., Harmel, R.D., Van Griensven, A., Van Liew, M.W. and Kannan, N., 2012. SWAT: Model use, calibration, and validation. Transactions of the ASABE, 55(4), pp.1491-1508.

13. Nobert, J. and Jeremiah, J., 2012. Hydrological response of watershed systems to land use/cover change. a case of Wami River Basin. The Open Hydrology Journal, 6(1), pp.78-87.

14. Vilaysane, B., Takara, K., Luo, P., Akkharath, I. and Duan, W., 2015. Hydrological stream flow modelling for calibration and uncertainty analysis using SWAT model in the Xedone river basin, Lao PDR. Procedia Environmental Sciences, 28, pp.380-390.

15. Kebede, A., Diekkrüger, B. and Moges, S.A., 2014. Comparative study of a physically based distributed hydrological model versus a conceptual hydrological model for assessment of climate change response in the Upper Nile, Baro-Akobo basin: a case study of the Sore watershed, Ethiopia. International Journal of River Basin Management, 12(4), pp.299-318, 2014.

16. Mengistu, K.T., 2009. Watershed hydrological responses to changes in land use and land cover, and management practices at Hare Watershed, Dissertation Thesis, Research Institute for water and Environment, Universität Siegen, Ethiopia.

17. Gashaw, T., Tulu, T., Argaw, M. and Worqlul, A.W., 2018. Modeling the hydrological impacts of land use/land cover changes in the Andassa watershed, Blue Nile Basin, Ethiopia. Science of the Total Environment, 619, pp.1394-1408.

18. Getachew, H.E. and Melesse, A.M., 2012. The impact of land use change on the hydrology of the Angereb Watershed, Ethiopia. International Journal of Water Sciences, 1(4), pp.1-7. 


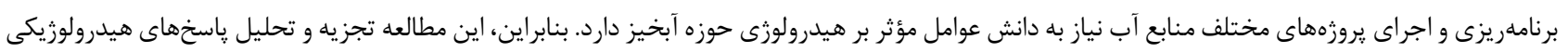

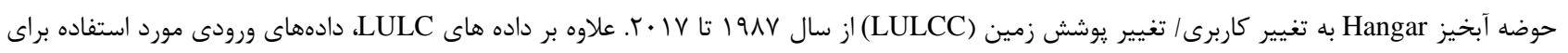

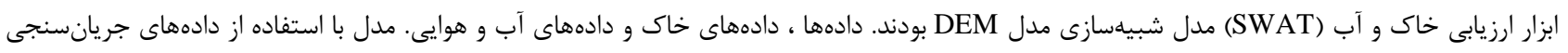

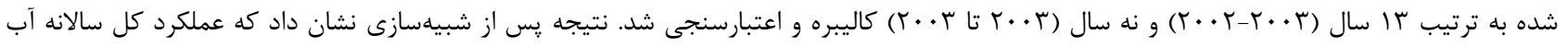

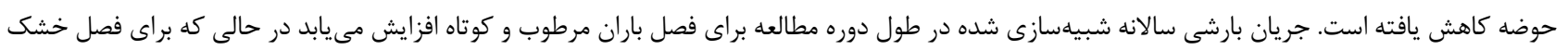

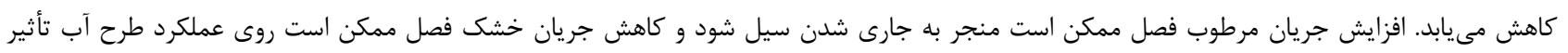

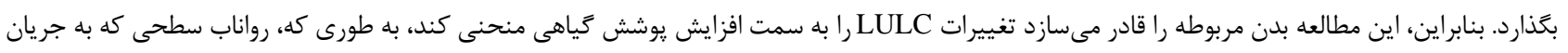

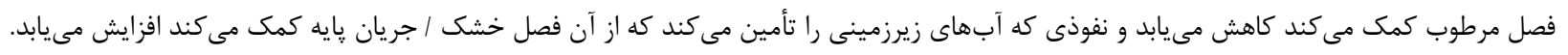

